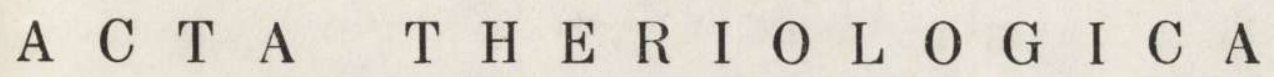 \\ VOL. XIV, 14: 181-190. \\ BIAEOWIEŻA \\ 30.VIII.1969
}

\author{
Andrzej G O R E C K I
}

\section{Metabolic Rate and Energy Budget of the Striped Field Mouse*}

[With 7 Tables \& 2 Figs.]

\begin{abstract}
In the striped field mouse, Apodemus agrarius ( $\mathrm{P}$ a 11 a s, 1771), deriving from the neighbourhood of Warszawa $(N=98)$ the average daily metabolic rate $(A D M R)$ and resting metabolic rate $(R M R)$ were studied in winter and summer. $A D M R$ was determined in daily runs in 9 liters metabolic chambers while $R M R$ was measured in $1-2 \mathrm{hr}$ experiments in small cages. $A D M R$ determined in the temperature of $20^{\circ} \mathrm{C}$ is equal to $0.552 \mathrm{kcal} / \mathrm{g} /$ day in summer and $0.573 \mathrm{kcal} / \mathrm{g} /$ day in winter in mice with average body weight of $20.5 \mathrm{~g}$. The intensity of heat production for thermoregulation in the range of temperatures of natural habitat amounted to $7.75 \% /{ }^{\circ} \mathrm{C}$ in winter and $3.71 \% /{ }^{\circ} \mathrm{C}$ in summer. During maximum activity the metabolism of mice increases by approximately $130 \%$ (minimum $3.31 \mathrm{ccm} \mathrm{O}_{2} / \mathrm{g} / \mathrm{hr}$ on the average, maximum $7.65 \mathrm{ccm} \mathrm{O}_{2} / \mathrm{g} / \mathrm{hr}$ ). Mice kept in groups of 2 or 3 animals decrease their metabolism by $28 \%$ on the average. In both seasons the daily activity rhytm of mice showed a two peaks pattern, with the main peak occurring at night. The mean period of the out-of-the-nest activity in summer and winter amounted to $4 \mathrm{hr} 36 \mathrm{~min}$. ADMR was assumed as a basis for the construction of daily energy budget $(D E B)$ of the field mouse. To calculate $D E B$ the heat production for thermoregulation in the nest and outside as well as corrections for the effect of huddling and the cost of reproduction were taken into consideration. $A D M R$ calculated from the regression equation: $M=$ 15.2 W-0.40 was used for the construction of $D E B$ for mice of body weights 8 to $28 \mathrm{~g}$. The values of $D E B$ varied from 0.513 to 0.845 $\mathrm{kcal} / \mathrm{g} / \mathrm{day}$ in winter and from 0.553 to $0.776 \mathrm{kcal} / \mathrm{g} / \mathrm{day}$ in summer.
\end{abstract}

\section{INTRODUCTION}

The knowledge of daily energy requirement of small rodents is essential for the calculation of energy flow through the population of these animals. The daily costs of maintenance of rodents are easily and accurately determined by taking into consideration their average metabolic rate $(A D M R)$, resting metabolic rate $(R M R)$ and basal metabolic rate $(B M R)$. The model of the bioenergetics based on $A D M R$ is simple and empirical, and the corrections applied are reduced to the

* This study was carried out under the Small Mammal Project of the International Biological Programme in Poland. 
out-of-the-nest activity, the effect of huddling and costs of reproduction (G r odziński \& Górecki, 1967).

The striped field mouse belongs to 2 species of rodents dominating in the field ecosystems of Central Europe. Due to this fact it was selected for detailed studies under the Small Mammals Project included in the International Biological Programme in Poland.

\section{MATERIAL AND METHODS}

The striped field mice, Apodemus agrarius ( $\mathrm{P}$ a $11 \mathrm{as}, 1771$ ), used in the experiments were captured in Eazienkowski Park in Warszawa ${ }^{1}$ ). Before every measurement the animals were acclimatized to laboratory conditions for $2-3$ days with the light rhytm resembling the natural one (S mirin, 1961; G r o dzin ski, $1965^{2}$ ); Górecki, 1966). Metabolism of mice was determined by the oxygen consumption with two independent procedures differing in the duration of measurements as well as in the size of metabolic chambers.

The average daily metabolic rate was measured in the Morrison closed system respirometer in $9 \mathrm{l}$. chambers in $20^{\circ} \mathrm{C}$ ( $\mathrm{M}$ or ris o $\mathrm{n}, 1951$; $\mathrm{M}$ or ris on \& $\mathrm{Gro}$ $\mathrm{dzi}$ ńs ki, 1968). On the whole $A D M R$ was determined in 44 mice in winter and summer (Table 1).

Table 1.

Animals used for measurements of $A D M R$.

\begin{tabular}{|l|c|c|c|c|}
\hline \multicolumn{1}{|c|}{ Season and Month } & $\begin{array}{c}\text { Number of } \\
\text { mice }\end{array}$ & $\begin{array}{c}\text { Sex } \\
\sigma^{*} \%\end{array}$ & $\begin{array}{c}\text { Body weight } \\
\text { in } \mathrm{g} \pm S . D .\end{array}$ & C. V. in $\%$ \\
\hline Summer - August & 23 & $14+9$ & $20.55 \pm 2.91$ & 14.2 \\
Winter - February & 21 & $12+9$ & $20.55 \pm 3.12$ & 15.4 \\
\hline Total and Means & 44 & $26+18$ & $20.41 \pm 3.01$ & 14.8 \\
\hline
\end{tabular}

The resting metabolic rate was measured in a modified respirometer of the Kalabukhov - Skvortzov system in small cages ( $\mathrm{Kalabukhov}, 1962) . \quad R M R$ and thermoregulation in the field mouse were estimated in the range of temperature from 0 to $30^{\circ} \mathrm{C}$ in $10^{\circ}$ intervals. Total number of determinations was 156 employing 40 mice in both seasons (Table 6, see page 186).

Moreover, the "huddling effect " was studied by measuring $A D M R$ of a group consisting of 2 or 3 animals kept together in the metabolic chamber and comparing the result with the $A D M R$ value obtained for the same mice studied separately. For this purpose 21 daily runs of the $A D M R$ were carried out. Additionally the "nest effect « was determined in 8 field mice by measuring $A D M R$ in chambers lacking the nest house.

Parallel to $A D M R$ measurements the daily rhytm and the sum of daily activity of the same animals in metabolic chambers were recorded. The nest houses equipped with two way switches in order to register the time of staying of the animal in the nest or outside were used (Górecki, 1968; Górecki \& $\mathrm{Ha}$ -

1) The author is greatly indebted to Mrs. K. Adamczewska-Andrzejewska, M. Sc. and Dr. R. Andrzejewski for providing the mice used in the experiments.

2) Grodzins i i W., "Program of bioenergetics studies on the productivity of small rodents«, MS. 
nusz, 1968). Additional the locomotoric activity of animals was also registered and expressed as the time of running of the animal on the activity wheel installed inside the cage (G ó recki, 1968).

Oxygen consumption, time of staying in the nest and outside as well as time of running on the activity wheel were registered on the Jaquet polygraph tape (at the tape speed $180 \mathrm{~mm} / \mathrm{hr}$ ), while the number of wheel turns was recorded by using the counter. The $t$-test was applied for the evaluation of statistical significance of the observed differences.

\section{RESULTS}

\section{Average Daily Metabolic Rate}

$A D M R$ of the field mice determined in $20^{\circ} \mathrm{C}$ is almost identical in summer and winter $(0.573$ and $0.552 \mathrm{kcal} / \mathrm{g} /$ day). The difference amounts to $4 \%$ only and is not significant. When computing the oxygen consumption into calories (Table 2) the respiratory quotient $(R Q)$ equal to

Table 2.

Average daily metabolism rate $(A D M R)$, maximum and minimum metabolism rate of the field mouse in summer and winter. All the values are relating to $20^{\circ} \mathrm{C}$.

\begin{tabular}{|c|c|c|c|c|c|c|c|c|}
\hline \multirow{2}{*}{ Season } & \multirow{2}{*}{$\mathrm{N}$} & \multirow{2}{*}{$\begin{array}{c}\text { Body } \\
\text { temp. } \\
{ }^{\circ} \mathrm{C}\end{array}$} & \multicolumn{2}{|c|}{ 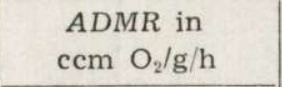 } & \multicolumn{4}{|c|}{$D M R$ in ccm $\mathrm{O}_{2} / \mathrm{g} / \mathrm{h}$} \\
\hline & & & Avg $\pm S . D$. & $\begin{array}{l}\text { C. } V \text {. } \\
\text { in } \%\end{array}$ & $\begin{array}{r}\text { Max. } \\
\pm S . D .\end{array}$ & $\begin{array}{l}\text { C. V. } \\
\text { in } \% \\
\end{array}$ & $\begin{array}{r}\text { Min. } \\
\pm \quad S . D .\end{array}$ & $\begin{array}{l}\text { C. V. } \\
\text { in } \%\end{array}$ \\
\hline Summer & 23 & 36.9 & $4.79 \pm 0.73$ & 15.2 & $7.54 \pm 0.85$ & 11.3 & $3.25 \pm 0.44$ & 13.5 \\
\hline Winter & 21 & 35.8 & $4.97 \pm 0.65$ & 13.1 & $7.75 \pm 0.81$ & 10.4 & $3.37 \pm 0.47$ & 13.9 \\
\hline Mean for year & - & 36.4 & $4.88 \pm 0.69$ & 14.1 & $7.65 \pm 0.83$ & 10.8 & $3.31 \pm 0.46$ & 13.7 \\
\hline
\end{tabular}

Table $\mathrm{s}$.

Relationship of $A D M R$ and motoric activity of field mice.

\begin{tabular}{|l|c|c|c|}
\hline & $\begin{array}{c}\text { Body weight, } \\
\mathrm{g}\end{array}$ & $\begin{array}{c}A D M R \\
\text { (kcal/g/day) }\end{array}$ & DMR $\frac{\text { Max }}{\text { Min }}$ \\
\hline Mice running on the wheel & 23.2 & 0.562 & 2.96 \\
Mice non-running on the wheel & 23.2 & 0.486 & 2.43 \\
Difference in per cents & 0 & 16 & 20 \\
Significance *) & - & + & + \\
\hline
\end{tabular}

*) + significant, - non-significant difference.

0.82 was assumed, corresponding to the caloric value of $4.8 \mathrm{kcal}$ per 11 . of oxygen.

The ratio of maximum and minimum oxygen consumption is very similar in both seasons and equal to 2.31 on the average (Table 2). 
Daily activity pattern of field mice was expressed as oxygen consumption in $2 \mathrm{hr}$ intervals (Fig. 1). The highest metabolism of the studied animals appeared during the night in both seasons (Fig. 1). Body temperature (rectal) measured before and after every determination of $A D M R$ was higher in summer by approximately $1^{\circ} \mathrm{C}$ (Table 2).

$A D M R$ determined in body seasons for a group of mice showing high activity on the running wheel installed in the metabolic chamber was compared with corresponding figures obtained for mice with did not used the wheel (Table 3). The mean time of activity of mice running on the wheel markedly exceeded the mean activity of all the animals during a year (Table 5).

Table 4.

Relationship of $A D M R$ and body weight of mice in summer.

\begin{tabular}{|c|c|c|}
\hline Body weight, $\mathrm{g}$ & Number of mice & ADMR \\
\hline $13.1-18.0$ & 8 & 0.704 \\
$18.1-24.0$ & 9 & 0.527 \\
24.0 & 6 & 0.481 \\
\hline Avèrage & - & 0.552 \\
\hline
\end{tabular}

Table 5.

Seasonal changes of the daily activity of field mice.

\begin{tabular}{|l|c|c|c|cc|}
\hline \multirow{1}{*}{ Season } & $\begin{array}{c}\text { Number of } \\
\text { animal s }\end{array}$ & \multicolumn{4}{|c|}{ Activity out-of-the-nest } \\
\cline { 3 - 6 } & Minutes \pm S. D. & C. V. in $\%$ & Hours & and minutes \\
\hline Summer & 14 & $268.0 \pm 24.3$ & 9.1 & 4 & 28 \\
Winter & 15 & $284.0 \pm 31.3$ & 11.0 & 4 & 44 \\
\hline Means for year & - & $276.0 \pm 27.8$ & 10.0 & 4 & 36 \\
\hline
\end{tabular}

$A D M R$ of field mice does not exhibit a statistically significant variability related to sex. On the other hand the apparent correlation with the body size of animals is visible (Table 4). The relation between average daily metabolic rate $(M)$ and body weight $(W)$ may by expressed by general equation: $M=15.2 W^{-0.40}$ (see page 187 , Table 7).

\section{Daily Activity of Field Mice}

The total daily activity of mice was measured by the time of staying of the animal out-of-the-nest. These totals for winter and summer 
differ very little without reaching the level of statistical significance (Table 5). In both seasons the activity rhytm was characterized by a two-peaks bimodal pattern, mainly at night. One of the activity peaks appeared at nightfall, the other one - in the middle of night in summer, or just before daybreak in winter. The whole pattern of the out-of-the-nest activity corresponded fairly well to the rhytm obtained from oxygen consumption (Figs. 1 \& 2). Only 9 animals used to run on the

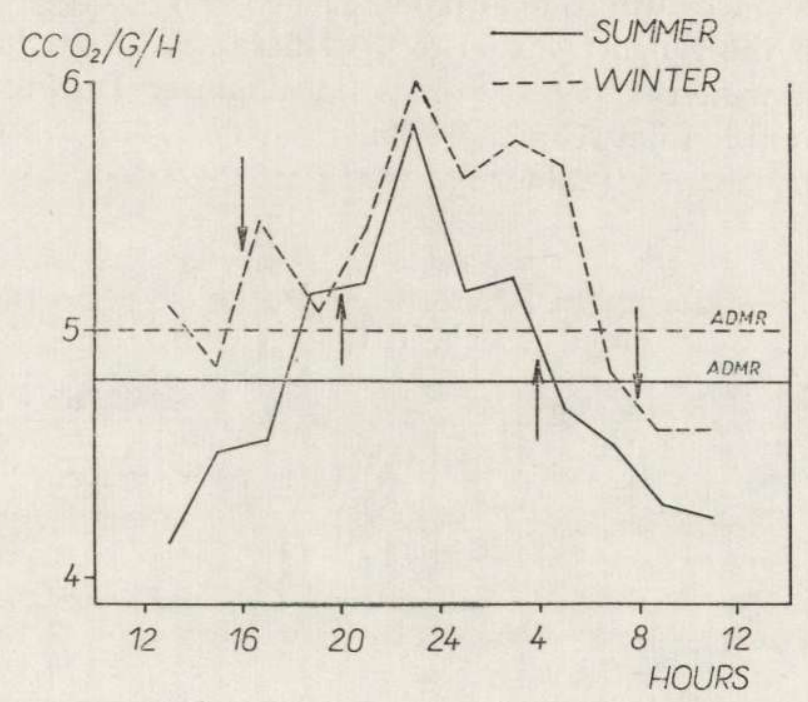

Fig. 1. Daily rhytm of metabolism rate in field mice in winter and summer. Solid line - summer, dashed line - winter, horizontal intermediate lines - ADMR levels. Arrows denote the duration of night.

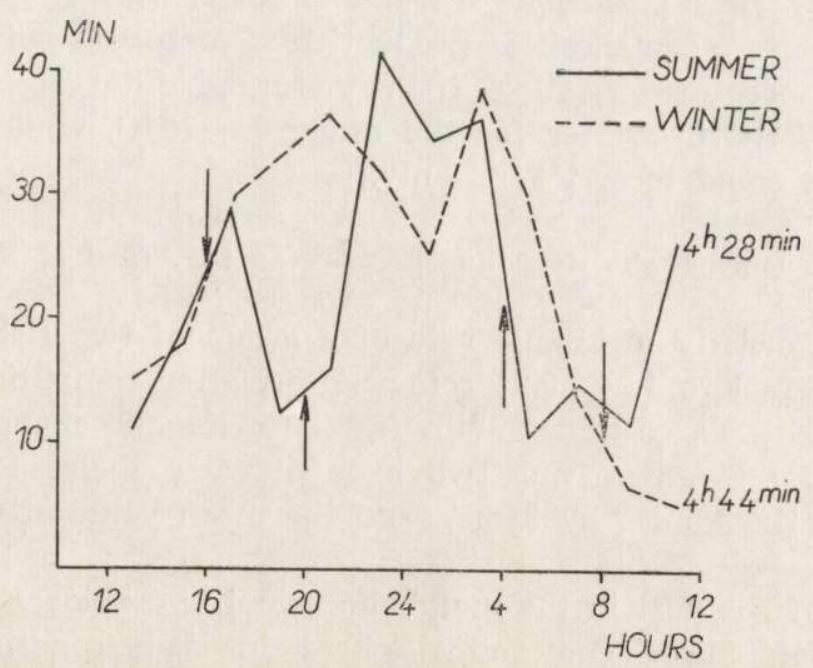

Fig. 2. Daily rhytm of the mouse activity out-of-the-nest, in minutes, during two seasons. Arrows denote the duration of night. 
wheel during both seasons, the average time spent on the wheel amounting to $63 \%$ of their out-of-the-nest activity.

\section{Thermoregulation}

Oxygen consumption by the field mice was lowest at $30^{\circ} \mathrm{C}$ in both seasons. The thermoneutral zone for these animals is probably located around this temperature ( $\mathrm{S} \mathrm{mirnov}, 1960 ; 1968)$. Oxygen consumption determined in the range from 30 to $0^{\circ} \mathrm{C}$ increases in absolute terms by 2.18 times in winter and 2.10 times in summer. During the winter oxygen consumption between the temperature of 10 and $0^{\circ} \mathrm{C}$ is slightly higher than in summer (Table 6).

Table 6.

Resting metabolism rate $(R M R)$ in mice expressed by oxygen consumption under different ambient temperatures.

\begin{tabular}{|c|c|c|c|c|c|c|c|c|}
\hline \multirow[b]{2}{*}{$\begin{array}{c}\text { Ambient } \\
\text { temp. } \\
\text { in }{ }^{\circ} \mathrm{C}\end{array}$} & \multicolumn{4}{|c|}{$\mathrm{Sum} \mathrm{mer}$} & \multicolumn{4}{|c|}{ W inter } \\
\hline & $\mathrm{N}$ & $\begin{array}{c}\text { Body } \\
\text { wt. } \\
\text { g }\end{array}$ & $\mathrm{cem} \mathrm{O} \mathrm{O}_{2} / \mathrm{g} / \mathrm{h} \pm S . D$ & $\begin{array}{l}\text { C.V. } \\
\text { in } \%\end{array}$ & $\mathrm{~N}$ & $\begin{array}{c}\text { Body } \\
\text { wt. } \\
\mathrm{g}\end{array}$ & $\mathrm{ccm} \mathrm{O}_{2} / \mathrm{g} / \mathrm{h} \pm$ S.D. & $\begin{array}{l}\text { C.V. } \\
\text { in } \%\end{array}$ \\
\hline 0 & 20 & 20.8 & $9.76 \pm 0.73$ & 7.5 & 16 & 19.3 & $10.10 \pm 0.82$ & 8.1 \\
\hline 10 & 20 & 20.6 & $6.98 \pm 0.71$ & 10.2 & 20 & 19.3 & $7.33 \pm 0.65$ & 8.8 \\
\hline 20 & 20 & 20.6 & $5.81 \pm 0.65$ & 11.2 & 20 & 20.8 & $5.17 \pm 0.73$ & 14.1 \\
\hline 30 & 20 & 21.2 & $3.15 \pm 0.54$ & 17.1 & 20 & 20.6 & $3.18 \pm 0.70$ & 22.0 \\
\hline
\end{tabular}

The heat production in per cents per $1^{\circ} \mathrm{C}$ within whole studied range of temperature is almost constant and amounts to 7.25 in winter and 6.99 in summer. When the heat production is compared only within the range of temperatures existing in the natural habitat of field mice, it reaches $7.75 \% /{ }^{\circ} \mathrm{C}$ in winter for the range $0-20^{\circ} \mathrm{C}$, while in summer $\left(10-20^{\circ} \mathrm{C}\right)$ is equal to $3.71 \% /{ }^{\circ} \mathrm{C}$ only.

4. Thermal Economy of the "Huddling Effect« and the Effect of Nest on $A D M R$

The average daily metabolic rate of a group of two field mice kept together is equal to $4.24 \pm 0.21 \mathrm{ccm} \mathrm{O}_{2} / \mathrm{g} / \mathrm{hr}$, after computing per gram of body weight. Three mice staying in the metabolic chamber consume $3.55 \pm 0.12 \mathrm{ccm} \mathrm{O}_{2} / \mathrm{g} / \mathrm{hr}$. Thus two mice decrease their metabolism by $16.9 \%$ while three mice by $29.2 \%$, and the mean value of these figures is $23.1 \%$.

The lack of the nest in the metabolic chamber considerably increased $A D M R$ of field mice. The animals kept in such conditions in $20^{\circ} \mathrm{C}$ consumed on the average $1.302 \mathrm{kcal} / \mathrm{g} / \mathrm{day}$. The same animals studied 
in chambers equipped with a nest consumed $0.464 \mathrm{kcal} / \mathrm{g} /$ day only. The increase of oxygen consumption by animals without the nest amounted to $180 \%$. The differences between both experimental groups were highly significant $(\mathrm{P}<0.001)$ while the body weight of animals was similar ( $0.6 \mathrm{~g}$ difference). The ratio of maximum to minimum oxygen consumption was lower in animals deprived of the nest and equal to 2.1 while in mice provided with the nest the corresponding figure was 2.9.

\section{DISCUSSION}

Empirical determination of all the data concerning the energy budget is not possible, hence daily energy budget $(D E B)$ is constructed on the basis of average daily metabolic rate with the application of essential corrections ( $\mathrm{Grodzi}$ śsi \& Górecki, 1967). The number of corrections and method of calculations may vary thus some details of the applied procedure are described below.

Table 7.

Computation of daily energy budget $(D E B)$ in field mice with different body weight, during winter and summer day.

\begin{tabular}{|c|c|c|c|c|c|c|c|c|}
\hline & & \multicolumn{6}{|c|}{ DEB in kcal/g/day } \\
\cline { 3 - 9 } $\begin{array}{c}\text { Body wt } \\
\text { in } \mathrm{g}\end{array}$ & $\begin{array}{c}A D M R \\
\text { ccm } \mathrm{O}_{2} / \mathrm{g} / \mathrm{h}\end{array}$ & $\begin{array}{c}\text { Summer } \\
\text { In the } \\
\text { nest }\end{array}$ & $\begin{array}{c}\text { Out of the } \\
\text { nest }\end{array}$ & Breed & Total & $\begin{array}{c}\text { In the } \\
\text { nest }\end{array}$ & $\begin{array}{c}\text { Out of the } \\
\text { nest }\end{array}$ & Total \\
\hline & & & & & & & & \\
\hline 8.0 & 6.65 & 0.622 & 0.154 & - & 0.776 & 0.622 & 0.223 & 0.845 \\
10.0 & 6.08 & 0.569 & 0.141 & - & 0.710 & 0.569 & 0.203 & 0.772 \\
12.0 & 5.66 & 0.530 & 0.131 & - & 0.661 & 0.530 & 0.189 & 0.719 \\
14.0 & 5.32 & 0.498 & 0.123 & - & 0.621 & 0.498 & 0.178 & 0.676 \\
16.0 & 5.04 & 0.472 & 0.117 & 0.102 & 0.691 & 0.472 & 0.169 & 0.641 \\
18.0 & 4.82 & 0.451 & 0.112 & 0.097 & 0.660 & 0.451 & 0.161 & 0.612 \\
20.0 & 4.62 & 0.432 & 0107 & 0.093 & 0.632 & 0.432 & 0.155 & 0.587 \\
22.0 & 4.44 & 0.416 & 0.103 & 0.089 & 0.608 & 0.416 & 0.149 & 0.565 \\
24.0 & 4.29 & 0.402 & 0.099 & 0.087 & 0.588 & 0.402 & 0.144 & 0.546 \\
26.0 & 4.16 & 0.389 & 0.096 & 0.084 & 0.569 & 0.389 & 0.139 & 0.528 \\
28.0 & 4.04 & 0.378 & 0.094 & 0.081 & 0.553 & 0.378 & 0.135 & 0.513 \\
\hline
\end{tabular}

Table 7 shows $A D M R$ of the field mice of body weight ranging from 8.0 to $28.0 \mathrm{~g}$ calculated from the regression equation $\left(M=15.2 W^{-0.40}\right)$ and $D E B$ construction for these animals. Since empirically determined $A D M R$ did not differ significantly in summer and winter, all the values were cumulated to obtain the mean $A D M R$.

In both seasons the mice stayed for $4.5 \mathrm{hr}$ out-of-the-nest ( $\mathrm{S} \mathrm{mir}$ nov, 1960; Table 3). The level of metabolism of mice in the nest 
temperature around $18^{\circ} \mathrm{C}$ (D a n i e l, 1964) exceeds by approximately $12 \%$ ADMR determined in $20^{\circ} \mathrm{C}$ (Table 4) but the group effect decreases the metabolism in the nest by $28 \%$ and actually surpasses the eventual correction.

The natural habitat of the field mouse consists of the field scrub or edges of the forest. The mean temperature of such habitat in Southern Poland was assumed to be around $0^{\circ} \mathrm{C}$ in winter and $18^{\circ} \mathrm{C}$ in summer (Klein, unpublished data). The intensity of heat production amounts in summer to 3.71 and in winter to $7.75 \% /{ }^{\circ} \mathrm{C}$. Consequently during the period of out-of-the-nest activity the dissipation of energy varies between $0.154-0.094 \mathrm{kcal} / \mathrm{g}$ in a summer day and $0.223-0.135 \mathrm{kcal} / \mathrm{g}$ in winter (Table 7).

The sex ratio in the mice population is close to $1: 1$ and approximately half of all the females is in the course of reproduction (Pelika $n$, 1965). Period of pregnancy and lactation increasing the female metabolism in voles by $70 \%$ ( $\mathrm{Kacz}$ marski, 1966; Trojan \& Wojciechowska, 1967; Migula, 1969). If the correction is computed for all the individuals in mice population, the increase of $A D M R$ amounts to $17.5 \%$. This correction was added only for animals of the body weight above $16.0 \mathrm{~g}$ (Table 7).

The mean body weight of the field mouse in summer approaches $20 \mathrm{~g}$ (H a itlinger, 1962; Pelikán, 1965). DEB calculated for such animal is equal to $12.64 \mathrm{kcal}$ in a summer day.

When the data from Table 7 are used for calculation of the energy flow through whole population $D E B$ values should be divided into several classes related to the body weight of mice. The construction of the table enables adaptation of the budgets to various conditions of climate and reproduction of the studied population.

$D E B$ of the field mouse may be checked by the nutrition methods. Daily costs of maintenance of the mouse in $20^{\circ} \mathrm{C}$ calculated from the assimilated food amount on the average to $0.528 \mathrm{kcal} / \mathrm{g} /$ day in animals fed with oat (D r o ż d $\dot{z}, 1968 ; 1968 \mathrm{a}$ ). $A D M R$ determined in the present study for animals of the same body weight and the same season is higher by $4 \%$ only. Similarly the daily energy requirement of the field mouse calculated by Grodzin ski (1961) from the resting metabolism rate $(R M R)$ is equal to $0.599 \mathrm{kcal} / \mathrm{g} /$ day in winter and differs from the figure determined in the present experiments by not more than $6 \%$. The higher accuracy of determination of $D E B$ of the field mouse may be possible after better understanding various conditions influencing the budget: microclimate of the nest and the natural habitat of mice, activity pattern of these animals as well as costs of reproduction under the natural conditions. 


\section{REFERENCES}

1. Daniel M., 1964: Temperature and humidity in the nest of Clethrionomys glareolus observed in continuous experiment. Acta Soc. Zool. Bohemosl., 38, 3: $278-279$.

2. Drożd $\dot{z}$ A., 1968: Studies on the digestibility and assimilation of foods in rodents. Ekol. pol., B, 14, 2: 147-159 [In Polish with English summ.].

3. D r o żd ż A., 1968a: Digestibility and assimilation of natural foods in small rodents. Acta theriol., 13, 21: 376-389.

4. G órecki A., 1966: Metabolic acclimatization of bank voles to the laboratory conditions. Acta theriol., 11, 18: 399-407.

5. Górecki A., 1968: Metabolic rate and energy budget of bank vole. Acta theriol., 13, 20: $341-365$.

6. Górecki A. \& Hanusz T., 1968: A simple indicator for registering the activity of small mammals. Ekol. pol. B, 14, 1: 33-37 [In Polish with English summ.].

7. Grodziński W., 1961: Metabolism rate and bioenergetics of small rodents from the deciduous forest. Bull. Acad. Pol. Sci. Cl. II, 9, 12: 493-499.

8. Grodziński W. \& Górecki A., 1967: Daily energy budgets of small rodents. [In: "Secondary Productivity of Terrestrial Ecosystems«, Ed. K. P etrus e wi c z]: 295-314, Państw Wyd. Nauk. Warszawa-Kraków.

9. Haitlinger R., 1962: Morphological variability in Apodemus agrarius (P a 11 a s, 1771). Acta theriol., 6, 8: 239-255.

10. K a c z marski F., 1966: Bioenergetics of pregnancy and lactation in the bank vole. Acta theriol., 11, 19: 409-417.

11. Kalabukhov N. I., 1962: Seasonal changes in the organism of mammals as the indicators of environmental effects. Symp. theriol., 156-174, Prague 1962.

12. Migula P., 1969: Bioenergetics of pregnancy and lactation in the european common vole. Acta theriol., 14, 13: 167-179.

13. Morrison P. R., 1951: An automatic manometric respirometer. Rev. Sci. Instrum., 22, 4: 264-267.

14. Morrison P. R. \& Grodziński W., 1968: Morrison respirometer and determination of ADMR. [In: "Methods of Ecol. Bioenergetics«, Ed. W. G r odziński \& R. Klekowski]. 153-163. Pol. Acad. Sci., Warszawa-Kraków.

15. Pelikán J., 1965: Reproduction, population structure and elimination of males in Apodemus agrarius ( $\mathrm{P}$ a 11.). Zool. listy, 14, 4: 317-332.

16. Smirin U. M., 1961: On the influence of the laboratory maintenance of Clethrionomys glareolus $\mathrm{S} \mathrm{chr}$. upon the animals chemical thermoregulation. Bjul. M. O. I. P., Biol., 63, 3: 20-24. [In Russian with English summ.].

17. Smirnov P. K., 1960: K voprosu o fizjologičeskih osobennostjah polevoj myši v svjazi s ee ekologiej. Tr. Peterg. Inst. L. G. U., 18: 202-213.

18. Smirnov P. K., 1968: Ekologo-fizjlologičeskoe issledovanie nekotoryh vidov gryzunov. Izd. Nauka. 1-133. Leningrad.

19. Trojan P. \& Wojciechowska B., 1967: Resting metabolism rate during pregnancy and lactation in the european common vole - Microtus arvalis (P a 11.). Ekol. pol., A, 15, 44: 811-817. 
Andrzej GÓRECKI

\section{METABOLIZM I BUDŻET ENERGETYCZNY MYSZY POLNEJ}

\section{Streszczenie}

U myszy polnych - Apodemus agrarius (P a 11 a s, 1771) z okolic Warszawy $(\mathrm{N}=98) \mathrm{w}$ zimie $\mathrm{i} w$ lecie studiowano średni metabolizm dobowy $(A D M R)$, oraz metabolizm spoczynkowy $(R M R)$. ADMR określano w przebiegach dobowych w dużych 9 litrowych komorach połączonych $\mathrm{z}$ automatycznym respirometrem systemu Morrison'a, a pomiary $R M R$ przeprowadzano w 1-2 godzinnych przebiegach w małych klatkach w respirometrze systemu Kalabukhova-Skvortzova (Tabele 1,3$)$.

ADMR mierzony w temperaturze $20^{\circ} \mathrm{C}$ wynosi w lecie $0,552 \mathrm{kcal} / \mathrm{g} / \mathrm{dobeq} \mathrm{i} \mathrm{w} \mathrm{zi-}$ mie $0,573 \mathrm{kcal} / \mathrm{g} /$ dobę u zwierząt o ciężarze ciała $20,5 \mathrm{~g}$ (Tabela 2). Intensywność produkcji ciepła na termoregulację $\mathrm{w}$ zakresie temperatur środowiska wynosi $\mathrm{w}$ zimie $7,75 \% /{ }^{\circ} \mathrm{C}$ i w lecie $3,71 \% /{ }^{\circ} \mathrm{C}$ (Tabela 4). Przy maksymalnej aktywności metabolizm myszy polnych wzrasta o około $130 \%$ (minimalny średnio $3,31 \mathrm{~cm}^{3} \mathrm{O} / \mathrm{g}$ / lgodzinę, maksymalny $7,65 \mathrm{~cm}^{3} \mathrm{O}_{2} /$ g/godzinę - Tabela 2). Myszy trzymane w grupach dwu i trzech zwierząt razem obniżają swój metabolizm średnio o $28 \%$.

Zarówno $\mathrm{w}$ zimie, jak i $\mathrm{w}$ lecie dobowy rytm aktywności myszy polnych posiadał wzorzec dwudzielny, głównie nocny (Ryc. 1, 2). Srednio w obu sezonach myszy polne były aktywne (poza gniazdem) 4 godziny 36 minut (Tabela 3 ).

$A D M R$ przyjęto jako podstawę do konstruowania dobowego budżetu energetycznego $(D E B)$ myszy polnych. Uwzględniono w nim produkcję ciepła na termoregulację poza gniazdem, poprawki na efekt grupowy i koszty rozrodu. $D E B$ obliczony dla myszy polnych o cieżarach ciała $8,0-28,0 \mathrm{~g}$ w oparciu o $A D M R$ wyliczony dla tych zwierząt $\mathrm{z}$ równania regresji: $M=15,2 \mathrm{~W}-0.40$ był zawarty $\mathrm{w}$ granicach $0,513-0,845 \mathrm{kcal} / \mathrm{g} / \mathrm{dobeq}$ w zimie i $0,553-0,776 \mathrm{kcal} / \mathrm{g} / \mathrm{dobeq}$ w lecie (Tabela 5). W przeliczeniu na mysz polną o ciężarze ciała $20,0 \mathrm{~g}$ wynosi to $12,6 \mathrm{kcal} /$ dzień $\mathrm{w}$ lecie i $11,7 \mathrm{kcal} / \mathrm{dzień} \mathrm{w}$ zimie.

Received, December 14, 1968.

Department of Animal Genetics and Organic Evolution, Jagiellonian University,

Kraków 2, Krupnicza 50, Poland. 